\title{
Investigation for the initiation of a loess landslide based on the unsaturated permeability and strength theory
}

\author{
Ping Li ${ }^{*}$, Xingting Zhang and Hao Shi
}

\begin{abstract}
Background: The Yanlian landslide, occurring on 21-22 October 2010, destroyed many facilities of a big oil refinery in Shaan'xi Province, China. It led to a suspending of the refinery work for a week and caused near 700 million RMB economic losses.

Results: Site exploration shows that the sliding mass is unsaturated-saturated loess. The groundwater is rich in the landslide and shortage in the surrounding slopes. Further investigation finds that the water drop released from the vapor heating furnaces on the top of the slope is the only source of the groundwater. Laboratory tests were performed to get the unsaturated strength parameters and hydraulic conductivity of the loess layers which were applied to a pre-failure slope model to simulate the water infiltration process and the stress field based on which the factor of safety is figured out to analyze the slope stability. Analysis shows that during the first ten years, the factor of safety has no prominent decrease. In the following 5 years, the slope stability decreases significantly till failure.

Conclusions: A little water infiltration has minor effects on slope stability for some time. As a result it is easy to be ignored. However, when the period of water infiltration is long enough to raise the groundwater level, it will have detrimental influence on the stability. In conclusion, any minor water produced by engineering or other activities for a long period may have harmful effect on slope stability. Therefore it is essential to take account of this kind of water and adopt measures to curb the surface water infiltration and to drain the groundwater.
\end{abstract}

Keywords: Unsaturated soil; Loess; Landslide; Strength parameters; Soil-water characteristic curve; Hydraulic conductivity function

\section{Background}

Loess landslides occurring in China lead to a huge economic losses every year (Liao et al. 2008; Bai et al. 2012; $\mathrm{Li}$ et al. 2012). It has been proved that rainfall, irrigation, water canal leakage, submerging of reservoir, melted snow and earthquake are the main factors triggering loess landslides (Lei, 1994; Dai and Lee 2001; Tu et al. 2009; Li et al. 2013; Zhang \& Peng 2014). However, there are no water resources and earthquake mentioned above before the Yanlian landslide occurred, which is located at Luochuan county, Shaanxi province, China as shown in Fig. 1, and the slopes nearby are stable even though they are higher and steeper than the failed. The landslide

\footnotetext{
* Correspondence: dcdgx07@chd.edu.cn

Department of Geological Engineering, Chang'an University, Xi'an, Shaan'xi,
} China moves down intermittently for two days and the people working on it has enough time to escape. So there is no fatality in the accident. The cause of the landslide is unclear and deeply concerned by the managers and researchers. The aims of the paper are to find the triggering factors by site exploration and to study the failure mechanism by laboratory tests and numerical analysis.

\section{Methods, results and discussions}

The landslide occurred on the erosive bank of the Luohe river which is the second tributary of the Yellow river. The first and the third terraces of the river develop on that bank and the second terrace is eroded off. The first terrace, about $5 \mathrm{~m}$ above the river bed, is flat and wide on which there is an oil refinery named Yanlian (Fig. 2). Against the rear of the first terrace is a $20 \mathrm{~m}$ high rock 


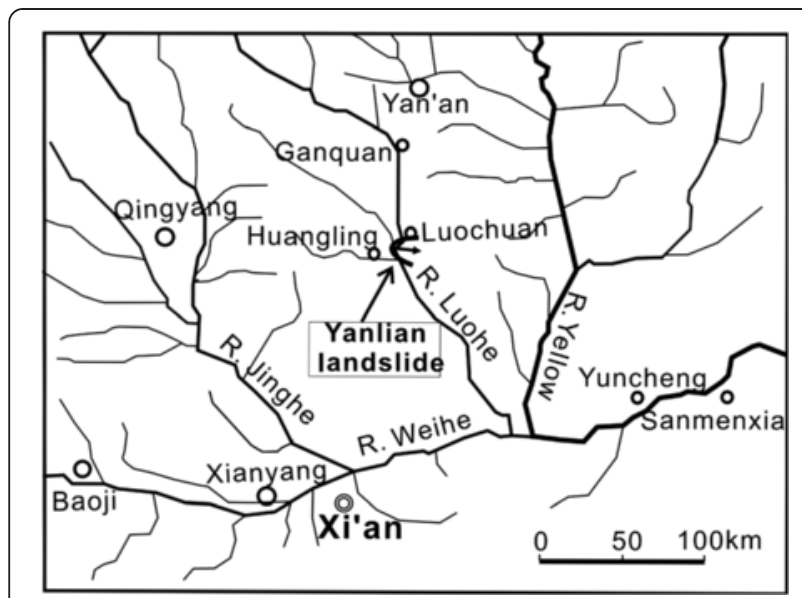

Fig. 1 Location of the Yanlian landslide

cliff composed of hard horizontal sandstone of the upper Triassic formation. The rock cliff is the base of the third terrace which is overlain by about $2 \mathrm{~m}$ thick alluvial pebble and nearly $50 \mathrm{~m}$ thick Quaternary loess successively. The pebble is filled with silt-sand and cemented by leached carbonate calcium, so it has a very low permeability. A spring flows out from the top of the pebble with an average flow quantity of about $0.5 \mathrm{~L} / \mathrm{s}$ (Fig. 3). The sliding mass, shearing out on the pebble bed, is totally loess. Around the failed slope, there are 34 large oil tanks lying on the top and 24 oil pipelines on the toe. A road wanders on the slope from the toe to the top. A boiler house and a coal storehouse stand on the first terrace against the cliff (Fig. 2).

Several days before October 21, 2010, a small part of loess at the toe of slope started to collapse from where a spring flowed out and buried part of the coal storage house. When the workers were trying to clear the collapsed material, the whole slope moved downwards for two days.

The landslide buried part of the coal storehouse (Fig. 2) and cut off all the 24 oil pipelines (Fig. 4) and the road. The oil tanks were only $5 \mathrm{~m}$ away from the head scarp

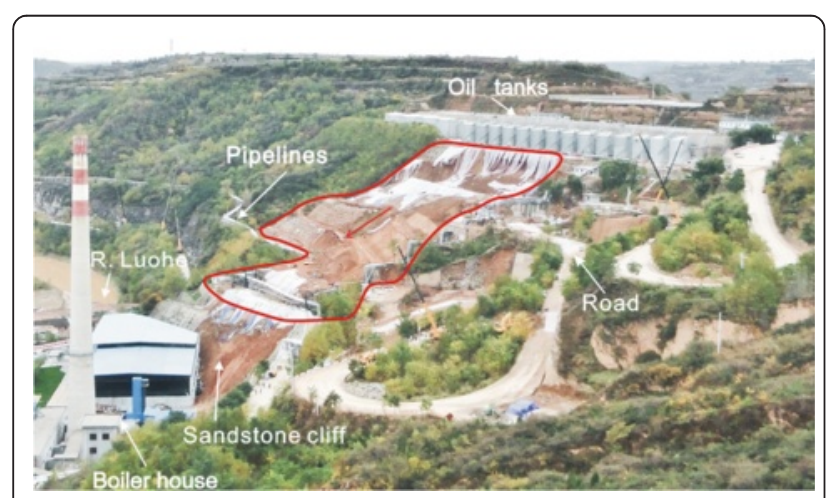

Fig. 2 The Yanlian landslide

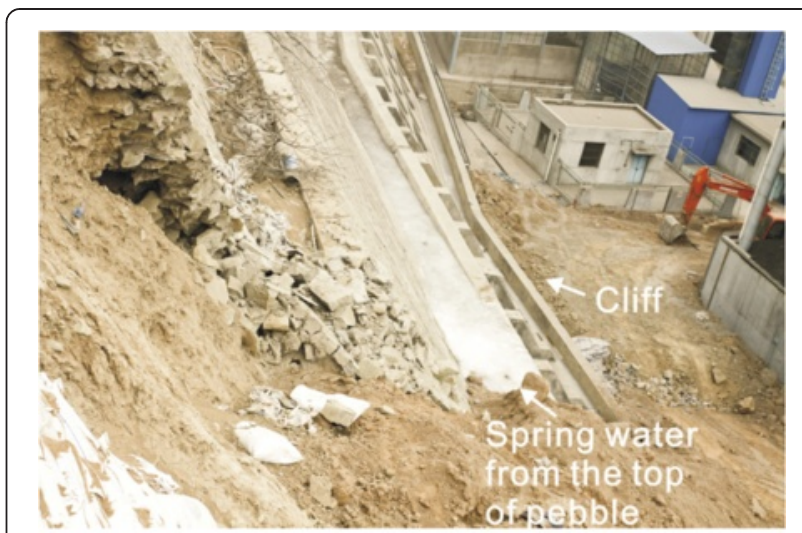

Fig. 3 The spring at the toe of the slope

(Fig. 5). The refinery had to stop working until 7 days later when the facilities were recovered. There were no fatalities but it caused 700 million RMB losses.

The surface gradient of the slope before failure is about $30^{\circ}$ and the vertical height is $47 \mathrm{~m}$. The failure mass has a width of $240 \mathrm{~m}$, a length of $150 \mathrm{~m}$, a thickness of $13.8 \mathrm{~m}$ and a total volume of $400,000 \mathrm{~m}^{3}$. The slope is composed of the unsaturated loess of Late $\left(\mathrm{Q}_{3}\right.$ loess), Medium $\left(\mathrm{Q}_{2}\right.$ loess $)$ and Early $\left(\mathrm{Q}_{1}\right.$ loess $)$ Pleistocene formations as shown in Fig. 6. The groundwater level is only $7 \mathrm{~m}$ deep at the center of the landslide, but no groundwater is found in the surrounding slopes. The region is generally shortage of groundwater because of the small precipitation (annually $596 \mathrm{~mm} / \mathrm{a}$ ) and the deep cut landform. The rainfall during the rainy season may quickly run off on the surface. Investigation on the top platform where oil tanks stand finds that there is lots of water vapor released from the pressure adjusters on the heating pipes which are used to keep the oil in the transfer pipes from frozen in winter (Fig. 7). The hot vapor condenses in winter and partly penetrates into the ground. The condensed water of the vapor is possibly the water source in the landslide

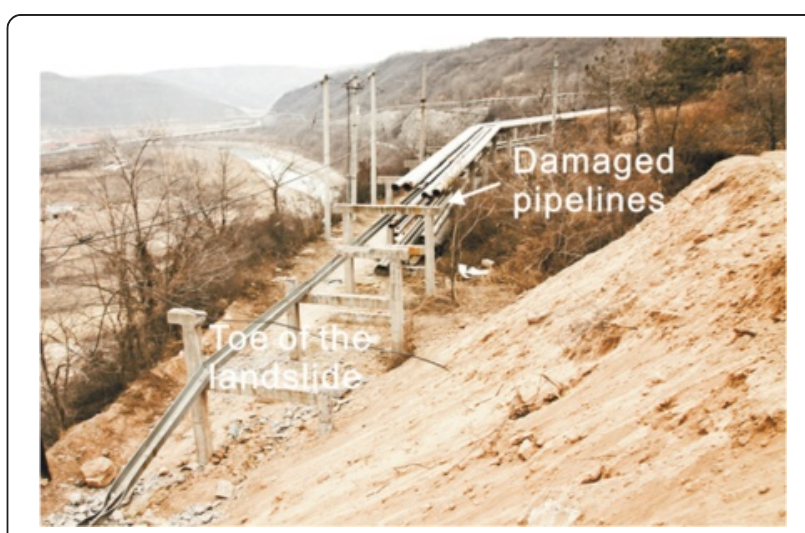

Fig. 4 The oil transfer pipes cut off by the landslide 


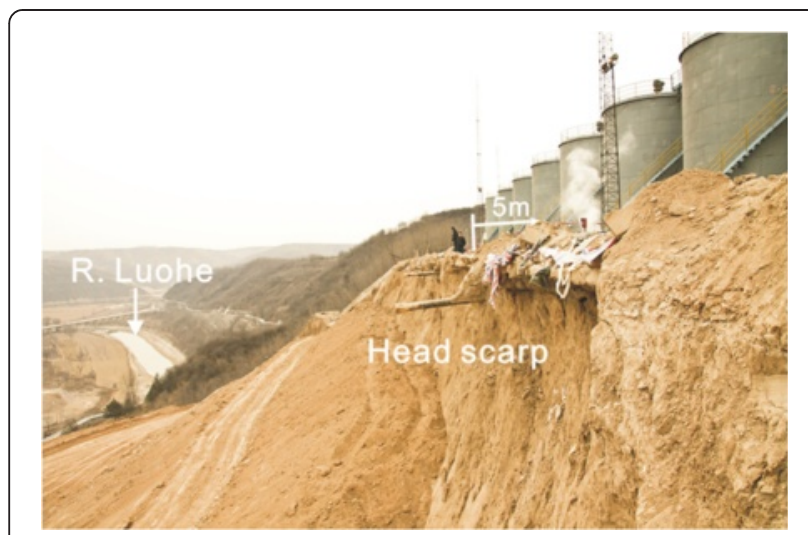

Fig. 5 The oil tanks hanging over the top of the head scarp

which has been ignored at the beginning. Therefore it is assumed that the groundwater in the landslide was generated by unsaturated infiltration of the condensed water drops and the landslide was trigged by the rising of the groundwater level.

\section{Determination of the loess physical properties}

The sliding mass and surface are composed of loess. Basic physical properties of loess include permeability, water content, density, plasticity, grain components. The coefficient of saturated permeability was measured through the falling head method. The water content and density were measured by oven drying and metal ring respectively. The plastic limit and liquid limit were measured by hand rolling and Cassgrande apparatus respectively. The results are shown in Table 1. Laser Particle Analysis were utilized to measure the grain size distributions of $\mathrm{Q}_{1}, \mathrm{Q}_{2}, \mathrm{Q}_{3}$ loess as shown in Fig. 8. It is shown that major component is silt $(0.005-0.05 \mathrm{~mm})$ taking up $60 \%$. The second is clay $(<0.005 \mathrm{~mm})$ taking up 20-40\%, and the minor component is fine sand

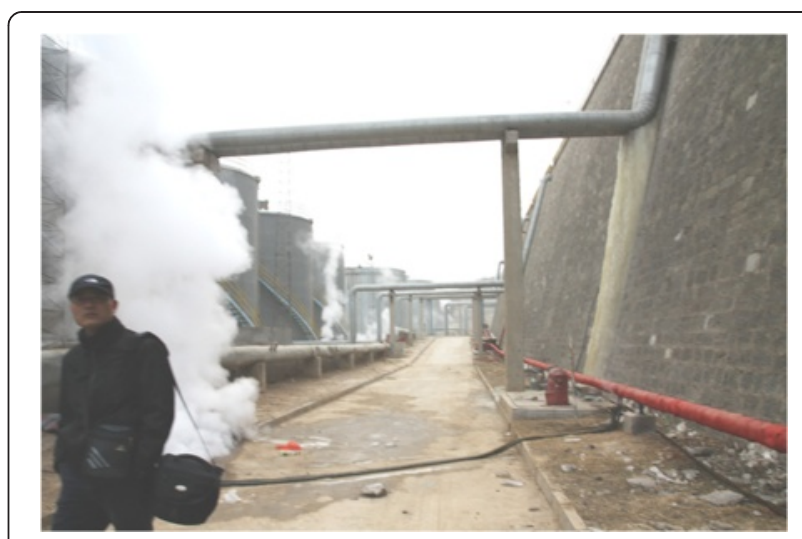

Fig. 7 The release water vapor from the pressure adjust valves on the heating pipes

$\left(>0.05 \mathrm{~mm}\right.$ ) less than $10 \%$. From $\mathrm{Q}_{3}$ to $\mathrm{Q}_{2}$ and $\mathrm{Q}_{1}$ loess, the mean particle size and the void ratio decrease as well as dry density increases. It demonstrates that the lower the loess layer lies, the longer the time of pedogenesis is and the heavier the load of consolidation experiences, the more compacted the loess is.

\section{Determination of SWCC and HCF}

Soil-water characteristic curves (SWCC) were measured in laboratory with undisturbed block specimens of $300 \mathrm{~mm} \times 300 \mathrm{~mm} \times 300 \mathrm{~mm}$ in dimensions. The specimens were collected from $\mathrm{Q}_{1}, \mathrm{Q}_{2}$ and $\mathrm{Q}_{3}$ loess respectively. The matric suctions were measured in wetting processby the TEN-15 tensiometer and the corresponding moisture contents by the oven-drying method. It was accomplished through the following steps: First, a block of specimen was air dried and a hole of $80 \mathrm{~mm}$ in depth and $300 \mathrm{~mm}$ in diameter was punched in the center of one face of the specimen. Second, insert a tensiometer into the hole with

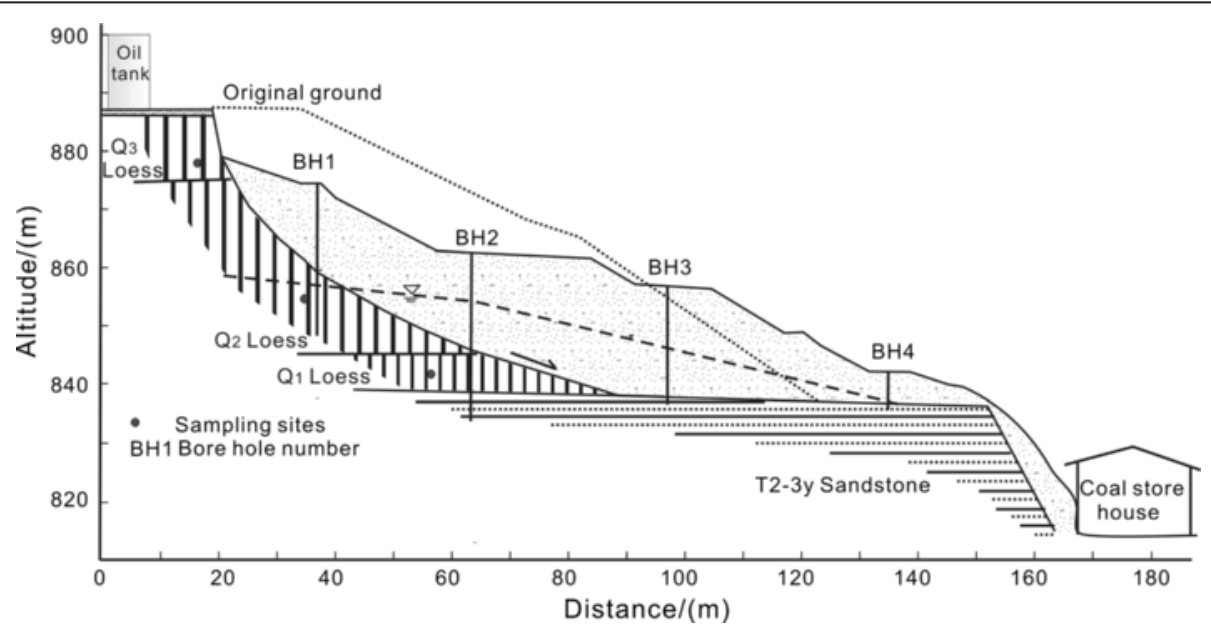

Fig. 6 The main longitude section of the Yanlian landslide 
Table 1 The basic physical properties of the loess samples

\begin{tabular}{|c|c|c|c|c|c|c|c|c|c|c|}
\hline \multirow[t]{2}{*}{ Loess } & Density & $\begin{array}{l}\text { Moisture } \\
\text { content }\end{array}$ & $\begin{array}{l}\text { Specific } \\
\text { gravity }\end{array}$ & $\begin{array}{l}\text { Dry } \\
\text { density }\end{array}$ & $\begin{array}{l}\text { Void } \\
\text { ratio }\end{array}$ & $\begin{array}{l}\text { Volumetric moisture } \\
\text { content }\end{array}$ & $\begin{array}{l}\text { Liquid } \\
\text { limit }\end{array}$ & $\begin{array}{l}\text { Plastic } \\
\text { limit }\end{array}$ & $\begin{array}{l}\text { Plastic } \\
\text { index }\end{array}$ & $\begin{array}{l}\text { Coefficient of } \\
\text { permeability }\end{array}$ \\
\hline & $\rho /\left(\mathrm{g} / \mathrm{cm}^{3}\right)$ & $w /(\%)$ & Gs & $\rho_{\mathrm{d}} /\left(\mathrm{g} / \mathrm{cm}^{3}\right)$ & $\mathrm{e}_{0}$ & $\theta /(\%)$ & $w_{\mathrm{L}} /(\%)$ & $w_{p} /(\%)$ & $\mathrm{I}_{\mathrm{p}} /(\%)$ & $\mathrm{k} /(\mathrm{m} /$ day $)$ \\
\hline$Q_{3}$ & 1.67 & 16.8 & 2.71 & 1.43 & 0.895 & 24.0 & 30.9 & 18.9 & 12.0 & 0.110 \\
\hline $\mathrm{Q}_{2}$ & 1.86 & 20.5 & 2.71 & 1.54 & 0.760 & 31.6 & 37.0 & 22.8 & 14.2 & 0.044 \\
\hline $\mathrm{Q}_{1}$ & 1.89 & 19.9 & 2.71 & 1.58 & 0.715 & 31.4 & 33.7 & 20.8 & 12.9 & 0.027 \\
\hline
\end{tabular}

the ceramic head saturated in advance and fill the gap with the same soil powder. Third, the specimen was enclosed with melted wax to make the moister distribution uniform. Some time later, read the data when the matric suction recorded by the gauge is stable. Then remove part of the enclosed wax and collect a bit of soil to measure the water content. So a set of data was obtained. In the next cycle, dropped some water in the specimen and enclosed it again. Repeat the above process to get a new set of data till the suction is 0 .

Because the range of tensiometer is less than $100 \mathrm{kPa}$, the measured data is applied to regress with the Fredlund \& Xing's (1994) eq. (1) to extend the curves to a higher suction range:

$$
\theta_{w}=C(\psi) \frac{\theta_{s}}{\left\{\ln \left[e+(\psi / a)^{n}\right]\right\}^{m}}
$$

Where $\theta_{w}$ is the volumetric moisture content; $\theta_{s}$ is the saturated volumetric moisture content; $\psi$ is the matric suction; $a$ is the approximate air-entry value of the soil; $n$ is a parameter that controls the slope at the inflection point in the SWCC; $m$ is a parameter related to the residual moisture content; $e$ is the natural number, 2.71828; and $C(\psi)$ is the correcting function defined by eq. (2).

$$
C(\psi)=1-\frac{\ln \left(1+\frac{\psi}{C_{r}}\right)}{\ln \left(1+10^{6} / C_{r}\right)}
$$

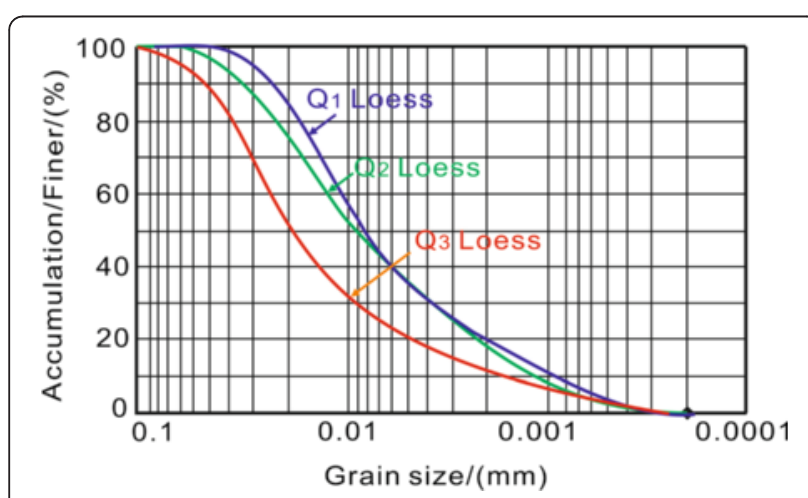

Fig. 8 Distribution curves of the particle size for the $Q_{3}, Q_{2}, Q_{1}$ loess
Where $C_{\mathrm{r}}$ is a constant related to the matric suction corresponding to the residual volumetric moisture content, a typical value for it is $1500 \mathrm{kPa}$.

The best fitting values of the parameters $a, m, n$ and the regressed SWCC are shown in Fig. 9, in which the dots are the measured values with tensiometer.

The hydraulic conductivity functions (HCF) is estimated empirically by the model proposed by Childs and Collis-Gorge (1950) and improved by Marshall (1958) and Kunze et al. (1968). The procedure is performed by dividing SWCC into $n$ equal moisture content increments. The relationship between the HCF and the matric suctions is calculated by the model. With the measured saturated coefficients of permeability in Table 1 and the SWCC curves in Fig. 9, the HCF are predicted and shown in Fig. 10.

\section{Measurement of the unsaturated strength parameters} $c_{0}{ }^{\prime}, \varphi^{\prime}$ and $\varphi^{b}$

Fredlund et al. (1978) unsaturated shearing strength is expressed as eq. (3).

$$
\tau_{f}=c_{0}^{\prime}+\left(\sigma-u_{a}\right) \tan \phi^{\prime}+\left(u_{a}-u_{w}\right) \tan \phi^{b}
$$

Where $\tau_{f}$ is the unsaturated shearing strength; $c^{\prime}{ }_{0}$ is the effective cohesion; $\phi^{\prime}$ is the effective friction angle; $\sigma-u_{\mathrm{a}}$ is the pure normal strength; $u_{\mathrm{a}}-u_{\mathrm{w}}$ is the matric suction and $\phi^{\mathrm{b}}$ is the friction angle related to matric suction.

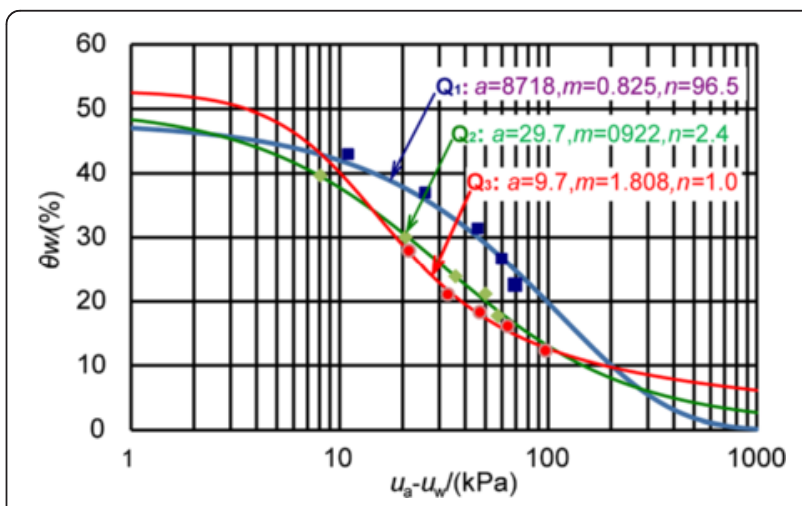

Fig. 9 The regressive SWCC curves of the loess, the dots are the measured values with TEN-10 tensiometer 


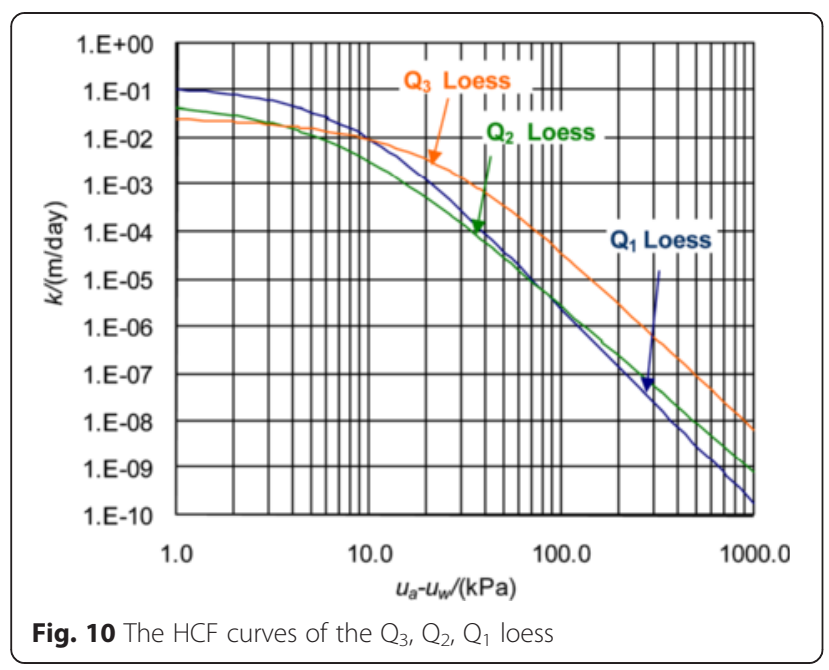

In which, $c^{\prime}{ }_{0}$ and $\phi^{\prime}$ can be measured by conventional direct shear test or triaxial test with saturated specimens. $\phi^{\mathrm{b}}$ can be measured by suction-controlled direct shear test or triaxial test.

Let

$$
c^{\prime}=c_{0}^{\prime}+\left(u_{a}-u_{w}\right) \tan \phi^{b}
$$

Where, $c^{\prime}$ can be considered as the total cohesion which includes the friction produced by matric suction. So, there is

$$
\tan \phi^{b}=\frac{c^{\prime}-c_{0}^{\prime}}{u_{a}-u_{w}}
$$

Here the total cohesion $c^{\prime}$ can be determined against $u_{\mathrm{a}}-u_{\mathrm{w}}$ by the conventional direct shear test or triaxial test.

For the three layers of $\mathrm{Q}_{3}, \mathrm{Q}_{2}$ and $\mathrm{Q}_{1}$ loess as shown in Fig. 6, $\mathrm{Q}_{3}$ lies on the top of the slope and fails due to the tension cracks, so $\mathrm{Q}_{3}$ loess should have lost its strength before the slope failure. $\mathrm{Q}_{2}$ loess fails at a shear zone in the middle of the slope, so consolidatedundrained triaxial tests for $\mathrm{Q}_{2}$ loess were conducted to simulate the stress state. $Q_{1}$ loess shears outward on the top of the pebble bed horizontally which has a fixed shear direction, so consolidated quick direct tests were conducted on $\mathrm{Q}_{1}$ loess to simulate the confined shear plane.

The moisture content of the loess underground is generally above $5 \%$ while the saturated moisture content is about $30 \%$. Specimens with initial moisture contents of $5,10,15,20,25$ and $30 \%$ were prepared for $\mathrm{Q}_{2}$ loess and $\mathrm{Q}_{1}$ loess repectively to do the laboratory tests. To make the specimen with intended moisture content, shape and dry each specimen first, then put it on a balance and drop water around it till the total weight is equivalent to the moisture content. After that, the specimens are enclosed in a rubber membrance for a week at least to make the moisture distribution uniform.

Triaxial tests for $\mathrm{Q}_{2}$ loess were performed on the specimens of $80 \mathrm{~mm}$ in height and $39 \mathrm{~mm}$ in diameter. The confining pressures were set at $100 \mathrm{kPa}, 200 \mathrm{kPa}, 300$ $\mathrm{kPa}, 400 \mathrm{kPa}$ and $500 \mathrm{kPa}$ rspectively. The rate of axial displacement was set at $0.04 \mathrm{~mm} / \mathrm{min}$ for all the tests. Direct shear tests for $\mathrm{Q}_{1}$ loess were conducted using the disk specimens of $20 \mathrm{~mm}$ in height and $50 \mathrm{~mm}$ in diameter. Normal stress was applied with $100 \mathrm{kPa}, 200$ $\mathrm{kPa}, 300 \mathrm{kPa}, 400 \mathrm{kPa}, 500 \mathrm{kPa}, 600 \mathrm{kPa}$ and the shear displacement rate was set at $0.02 \mathrm{~mm} / \mathrm{min}$.

The triaxial test results are showned in the forms of the maximam shear stress $q=\left(\sigma_{1}-\sigma_{2}\right) / 2$ against axial strain $\varepsilon_{1}$ and $q$ against average principle stess $p=\left(\sigma_{1}+\sigma_{2}\right) / 2$ in Fig. 11. It can be seen that the specimens with moisture contents lower than $10 \%$ have no pore watetr presure produced in the whole shearing process, but those with higer moisture contents produce pore water presure. The higher the moisture content, the higher the pore water presure is. Specimens with $5 \%$ moisture contents have remarkable peak values than that of $10 \%$ moisture contents under low confining pressure of $100 \mathrm{kPa}$. Meanwhile, most of the other specimens have realistic elasto-plastic and hardening stress-strain forms. Some of the high moisture content specimens have gentle softening stress-strain curves, while the strain soften can be attributed to the increase of pore water pressure. It manifests that the loess could maintain the stuctural strength in the condition of low moisture content and low confning pressure. For high moisture content and high confining pressure, the stucture would be broken during consolidation prior to shearing.

With the stress path $q-p$ curves, the effective strength $K_{\mathrm{f}}$ lines can be drawn as the common tangent lines of effective stress paths, and the total effective cohesion $c^{\prime}$ and friction angle $\phi^{\prime}$ can be calculated by intercept $b$ and gradient angles $\alpha$ of $K_{\mathrm{f}}$ lines with eq. (5). The obtained unsaturated strength parameters, the moisture contents, the calculated volumetric moisture contents and the matric suction obtained from the SWCC curves are listed in Table 2.

$$
\begin{aligned}
& c^{\prime}=b \cos ^{-1} \phi^{\prime} \\
& \phi^{\prime}=\sin ^{-1}(\tan \alpha)
\end{aligned}
$$

Where $b$ is the intercept and $\alpha$ is the gradient of $K_{\mathrm{f}}$ line respectively.

The data in Table 2 shows that the effective friction angle $\phi^{\prime}$ is independent of the moisture content. The range of the angles is between $24.5^{\circ}$ and $25.5^{\circ}$. The mean 

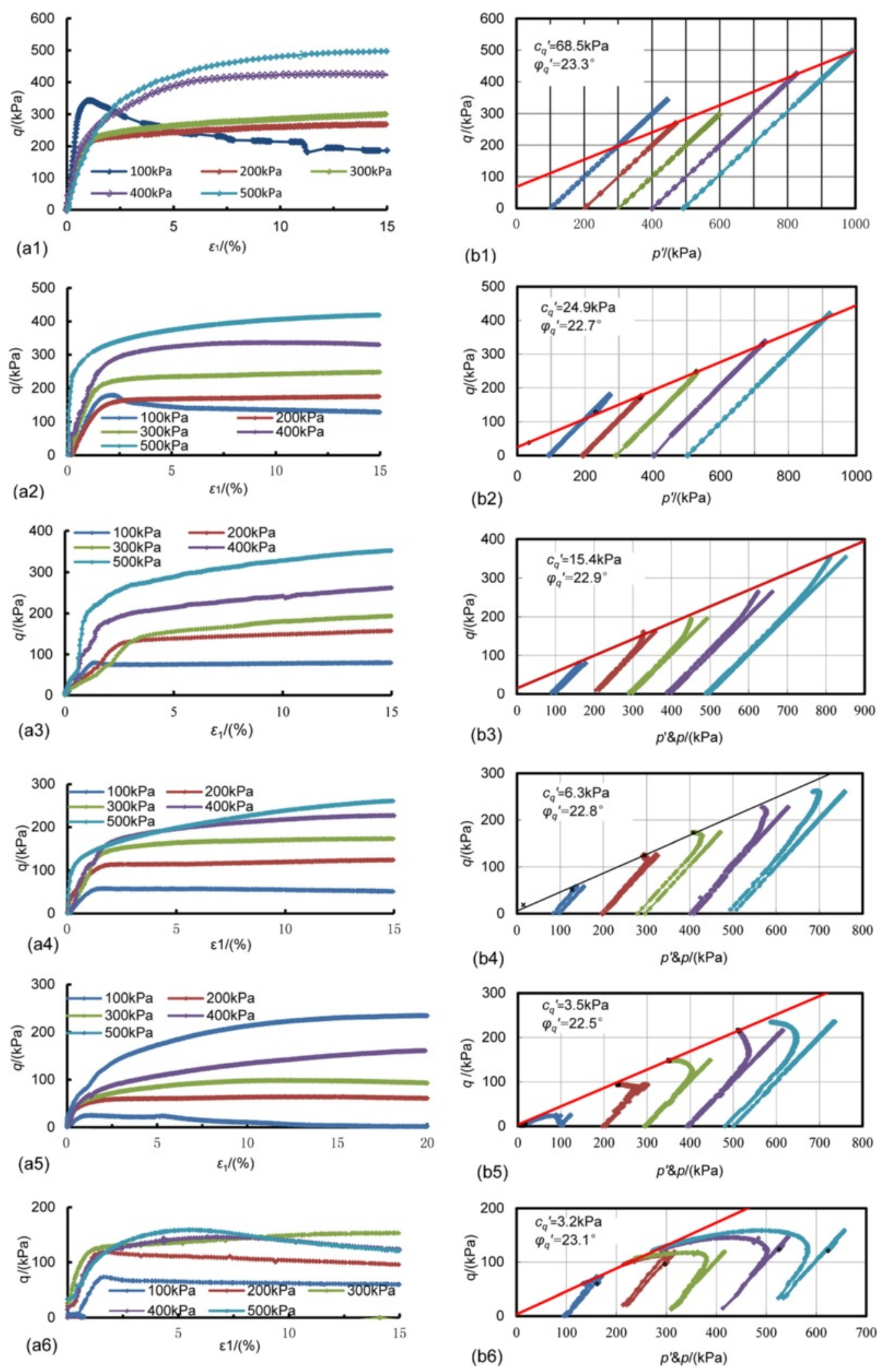

Fig. 11 Stress-strain curves and stress paths for the specimens of definite moisture contents (a1)-(a6) are the $q-\varepsilon_{1}$ curvesand (b1)-(b6) are the stress path $q$ - $p$ curves for the specimens with $w=5,10,15,20,25,30 \%$ respectively, wherein $q=\left(\sigma_{1}-\sigma_{2}\right) / 2, p=\left(\sigma_{1}+\sigma_{2}\right) / 2$ 
Table 2 The measured effective strength parameters and the relevant indexes for $\mathrm{Q}_{2}$ loess

\begin{tabular}{|c|c|c|c|c|c|}
\hline \multirow[t]{2}{*}{$\begin{array}{l}\text { Specimen } \\
\text { no. }\end{array}$} & \multirow{2}{*}{$\begin{array}{l}\text { Moisture } \\
\text { content } \\
w /(\%)\end{array}$} & \multirow{2}{*}{$\begin{array}{l}\text { Volumetric } \\
\text { moisture } \\
\text { content } \\
\theta_{w} /(\%)\end{array}$} & \multirow{2}{*}{$\begin{array}{l}\text { Matric } \\
\text { suction } \\
U_{a}-U_{w} /(\mathrm{kPa})\end{array}$} & \multirow{2}{*}{$\begin{array}{l}\text { Total } \\
\text { effective } \\
\text { cohesion } \\
c^{\prime} /(\mathrm{kPa})\end{array}$} & \multirow{2}{*}{$\begin{array}{l}\text { Effective } \\
\text { friction } \\
\text { angle } \\
\varphi^{\prime} /\left(^{\circ}\right)\end{array}$} \\
\hline & & & & & \\
\hline $\mathrm{T}_{1}$ & 5 & 7.7 & 200.5 & 74.6 & 25.5 \\
\hline $\mathrm{T}_{2}$ & 10 & 15.4 & 67.0 & 27.0 & 24.8 \\
\hline $\mathrm{T}_{3}$ & 15 & 23.1 & 28.7 & 16.7 & 25.0 \\
\hline $\mathrm{T}_{4}$ & 20 & 30.8 & 10.6 & 6.8 & 24.9 \\
\hline$T_{5}$ & 25 & 38.5 & 0.2 & 3.8 & 24.5 \\
\hline$T_{6}$ & 30 & 46.2 & 0.0 & 3.5 & 25.2 \\
\hline \multicolumn{3}{|c|}{ Strength parameters } & $\varphi^{\mathrm{b}}=19.5^{\circ}$ & $c_{0}^{\prime}=3.50 \mathrm{kPa}$ & $\varphi^{\prime}=25.0^{\circ}$ \\
\hline
\end{tabular}

value is $\phi^{\prime}=25.0^{\circ}$. The total effective cohesion $c^{\prime}$ has a reverse relation with the moisture content. It decreases prominently in the low moisture content range. As the moisture content exceeds the plastic limit ( $\mathrm{PL}=22.8 \%)$, it reaches to its minimum value $3.50 \mathrm{kPa}$ or so and keeps constant. So $c^{\prime}{ }_{0}$ is accepted as $3.50 \mathrm{kPa}$.

The curve of $c^{\prime}-c^{\prime}{ }_{0}$ verse $u_{a}-u_{w}$, shown in Fig. 12, expresses that the relationship of $c^{\prime}-c^{\prime}{ }_{0}$ and $u_{a}-u_{w}$ is linear and the gradient angle of the linear curve is $19.5^{\circ}$.

The stress-strain curves of the direct shear for $Q_{1}$ loess are shown in Fig. 13. It can be seen that the marked peak values appear in the cases of low normal stresses and low moisture contents, such as in the moisture contents of $5 \%$ and $10 \%$ under normal stress from $100 \mathrm{kPa}$ to $400 \mathrm{kPa}$. For the remaining specimens, the stress-strains show realistic elasto-plastic behavior or hardening, similar to the triaxial results of $\mathrm{Q}_{2}$ loess. Assuming $6 \mathrm{~mm}$ shear displacement as the failure point, the shear strength against mormal stress for each moisture content are ploted in Fig. 14, from which the total effective cohesions $c^{\prime}$ and effective friction angles $\phi^{\prime}$ can be calculated by eq. (5) and are listed in Table 3. The moisture contents, the calculated volumetric moisture

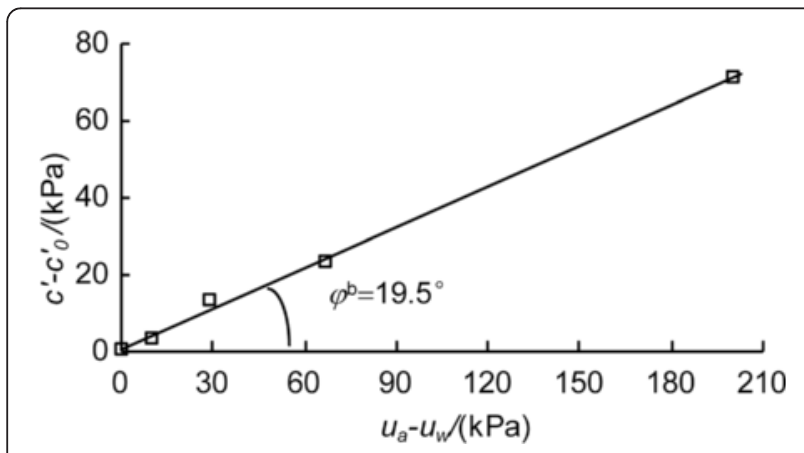

Fig. 12 The relation between $c^{\prime}-c_{0}^{\prime}$ against $u_{a}-u_{w}$ of the $Q_{2}$ loess contents and the matric suction determined by SWCC curves are also listed in Table 3.

Similar to the triaxial results for $\mathrm{Q}_{2}$ loess, the effective friction angle is independent of the moisture content. The range of the angles is between $29.4^{\circ}$ and $30.5^{\circ}$. The mean value is $\phi^{\prime}=30.0^{\circ}$. The total effective cohesion decreases with the increase of the moisture content and changes prominently in the low range. It reaches to the minimum value of $5.0 \mathrm{kPa}$ or so as the moisture content decreases to plastic limit $(\mathrm{PL}=20.8 \%)$. So $c^{\prime}{ }_{0}=5.0 \mathrm{kPa}$. Through the curve of $c^{\prime}-c^{\prime}{ }_{0}$ verse $u_{a}-u_{w}$ as shown in Fig. $15, \phi^{\mathrm{b}}$ can be determined to be $25.3^{\circ}$.

\section{Analysis for the landslide initiation mechanism}

To analyze the initiation mechanism of the landslide, a 2D FEM model of the slope before failure is built up to simulate the water seepage processes and to monitor the moisture field. The stress field and the strength variation with the moisture change are also analyzed. Fig. 16 shows the FEM model. Geo-studio SEEP and SIGMA software are utilized to simulate the seepage process and the stress fields, respectively.

The HCF of $\mathrm{Q}_{1}, \mathrm{Q}_{2}, \mathrm{Q}_{3}$ loess, the SWCC and the related strength parameters of $\mathrm{Q}_{1}, \mathrm{Q}_{2}$ loess have been fully documented above. The strength of $\mathrm{Q}_{3}$ loess can be neglected, so a low cohesion is assigned to it empirically and the friction angle is taken as zero. The deformation parameters of elastic module and Poisson's ratio have minor effect on the stress field, so values of these parameters for all the strata are assigned empirically. The strength of the bedrock is much higher than the loess strata, so a high cohesion and friction angle are assigned. The values for all the parameters needed in the simulation are summarized in Table 4.

The initial condition starts as water begins to drop in the zone of the oil tanks standing on top of the slope. By estimating the voulme of the dropping water into the ground in winter, a $20 \mathrm{~mm}$ high and $5 \mathrm{~m}$ wide water column is supposed to seep into the ground perday and continue for 100 days (winter days) a year. The rainfall is negleted. In addition, the initial moisture contents of the loess layers are defined by the moister content logging in the borehole in the nearby slope.

Geo-studio SEEP is used to simulate the seepage processes. The moisture field (expressed as pore water pressure field) is added into the Geo-studio SIGMA to simulate the stress and the strength variation under water infiltration. The sliding surface is fixed as the real occurred one, and the shear stress as well as shear strength at each point on the sliding surface can be figured out with the simulated stress states. The factor of safety $F \mathrm{~s}$ is defined by eq. (6) based on limit equilibrium theory. 

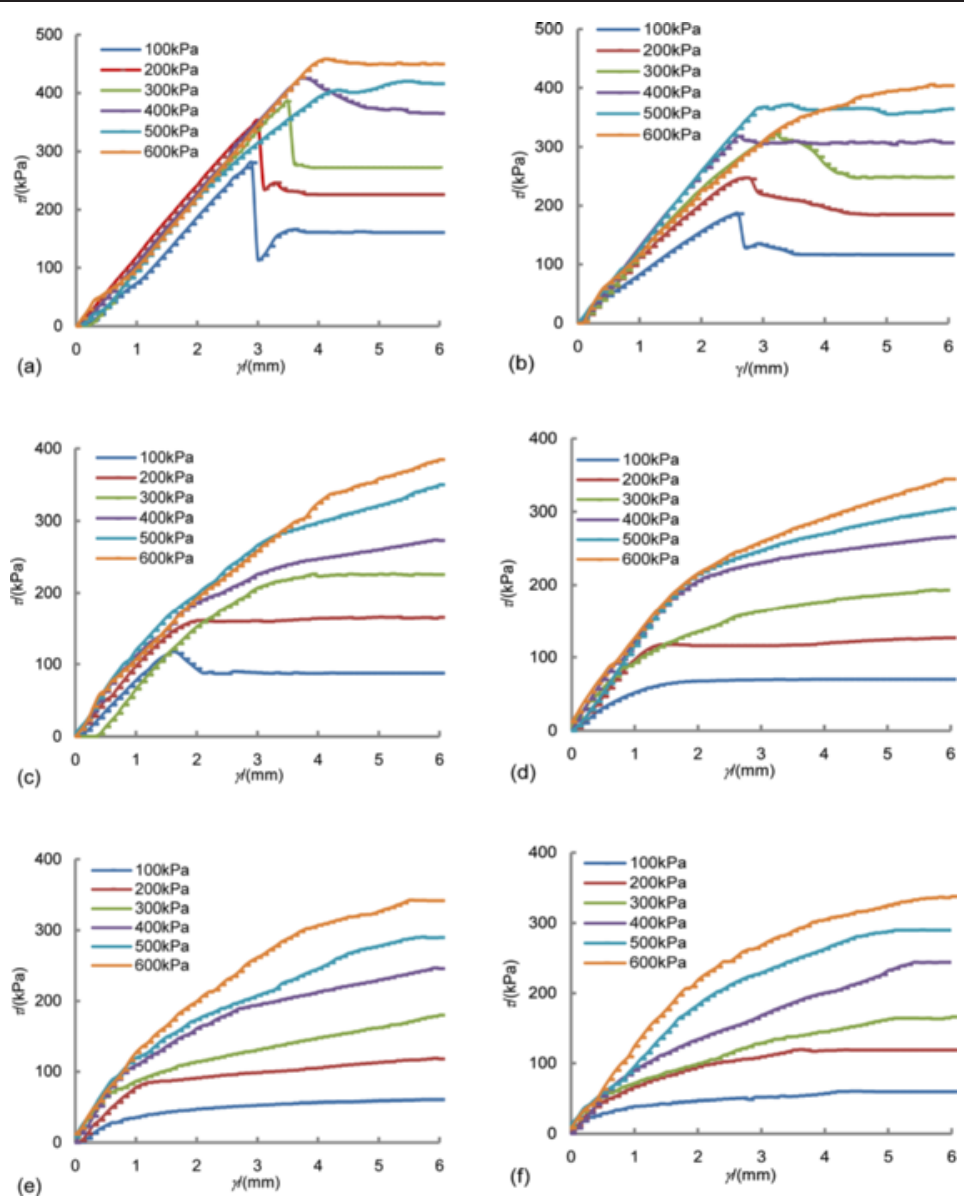

Fig. 13 The shear stress-strain curves of the test results for different moisture contents (a) $w=5 \%$; (b) $w=10 \%$; (c) $w=15 \%$; (d) $w=20 \%$; $(\mathbf{e}) w=25 \% ;(\mathbf{f}) w=30 \%$

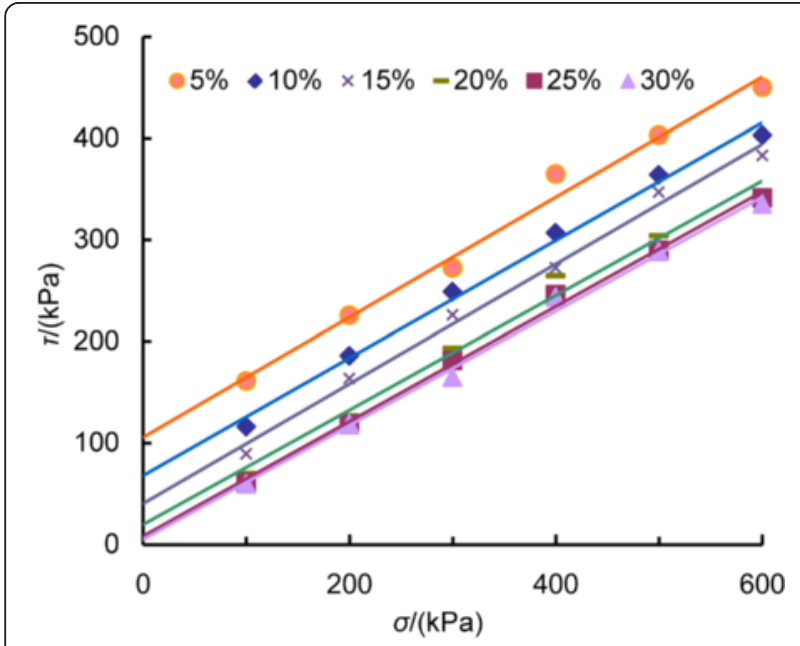

Fig. 14 The shear strength vs normal stress for different moisture contents
Table 3 The measured effective strength parameters and the relevant indexes for $\mathrm{Q}_{1}$ loess

\begin{tabular}{|c|c|c|c|c|c|}
\hline \multirow[t]{2}{*}{$\begin{array}{l}\text { Specimen } \\
\text { no. }\end{array}$} & $\begin{array}{l}\text { Moisture } \\
\text { content }\end{array}$ & $\begin{array}{l}\text { Volumetric } \\
\text { moisture } \\
\text { content }\end{array}$ & $\begin{array}{l}\text { Matric } \\
\text { suction }\end{array}$ & $\begin{array}{l}\text { Total } \\
\text { effective } \\
\text { cohesion }\end{array}$ & $\begin{array}{l}\text { Effective } \\
\text { friction } \\
\text { angle }\end{array}$ \\
\hline & $w /(\%)$ & $\theta_{w} /(\%)$ & $u_{a}-u_{w} /(\mathrm{kPa})$ & $c^{\prime} /(\mathrm{kPa})$ & $\varphi^{\prime} /\left(^{\circ}\right)$ \\
\hline $\mathrm{D}_{1}$ & 5 & 7.9 & 225.2 & 105.7 & 30.0 \\
\hline$D_{2}$ & 10 & 15.8 & 116.9 & 67.9 & 30.1 \\
\hline$D_{3}$ & 15 & 23.7 & 60.3 & 42.0 & 30.5 \\
\hline $\mathrm{D}_{4}$ & 20 & 31.6 & 24.3 & 19.4 & 29.4 \\
\hline$D_{5}$ & 25 & 39.5 & 0.0 & 7.9 & 29.6 \\
\hline$D_{6}$ & 30 & 47.4 & 0.0 & 5.0 & 29.5 \\
\hline \multicolumn{3}{|c|}{ Strength parameters } & $\varphi^{\mathrm{b}}=25.3^{\circ}$ & $c_{0}^{\prime}=5.0 \mathrm{kPa}$ & $\varphi^{\prime}=30.0^{\circ}$ \\
\hline
\end{tabular}




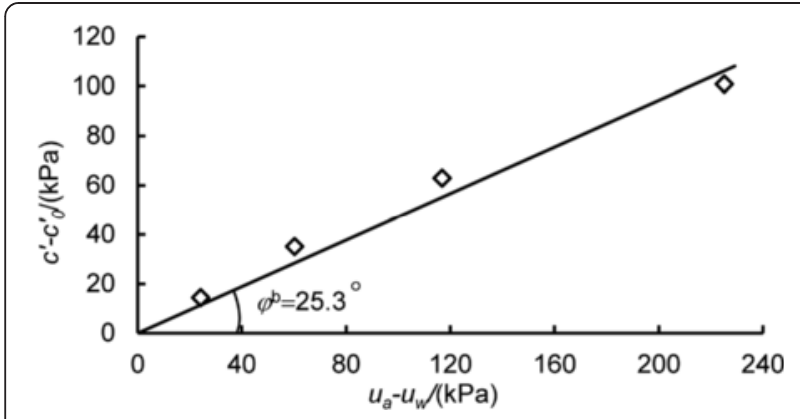

Fig. 15 Relation between $c^{\prime}-c_{0}^{\prime}$ and $u_{a}-u_{w}$ of the $Q_{1}$ loess

$$
F s=\frac{\int_{x_{A}}^{x_{B}} \tau_{f} d x}{\int_{x_{A}}^{x_{B}} \tau d x}
$$

Where $\tau_{f}$ is the shear strength of the sliding surface as defined by eq. (3); $\tau$ is the shear stress on the sliding surface; $x_{\mathrm{A}}$ and $x_{\mathrm{B}}$ are the horizontal coordinate of the end points of the sliding surface.

The simulations are conducted from the beginning of water dropping and the factor of safety is calculated as well till it fails. At last, it keeps stable for 15 years before failure. The period is agreement with the age of the oil tanks.

Figure 17 shows the simulated pore water pressure fields at specified time. For each year, the results at the ends of 100 days water dropping and after 265 days break are provided. It shows that in the first year, the moisture perches at the upper layer of the slope. And when stopping infiltrating, the moisture scatters and negative pore pressure decreases. In the $4^{\text {th }}$ year, moisture moves down to the impermeable rock bed and migrates along the boundary of $\mathrm{Q}_{3}$ and $\mathrm{Q}_{2}$ loess as well as the bedrock. When the infiltration stops, the wetting front moves laterally and the groundwater level decreases with the water extends outwards. However, at this time, just a little moisture invades the sliding surface, so the slope
Table 4 The values of the parameters for the slope simulation

\begin{tabular}{|c|c|c|c|c|}
\hline Strata & $\mathrm{Q}_{3}$ loess & $\mathrm{Q}_{2}$ loess & $\mathrm{Q}_{1}$ loess & Sandstone \\
\hline Elastic module $E /(\mathrm{kPa})$ & $10^{2}$ & $10^{3}$ & $10^{3}$ & $10^{5}$ \\
\hline Poisson's ratio $v$ & 0.35 & 0.35 & 0.33 & 0.20 \\
\hline Effective friction angle $\varphi^{\prime} /\left(^{\circ}\right)$ & 0.0 & 25.0 & 30.0 & 45.0 \\
\hline $\begin{array}{l}\text { Friction angle related to } \\
\text { suction } \varphi^{\mathrm{b}} /\left(^{\circ}\right)\end{array}$ & 0.0 & 195. & 25.3 & - \\
\hline $\begin{array}{l}\text { Saturated effective cohesion } \\
c_{0}^{\prime} /(\mathrm{kPa})\end{array}$ & 3.0 & 3.5 & 5.0 & 1000 \\
\hline Density $\gamma /\left(\mathrm{g} / \mathrm{cm}^{3}\right)$ & 1.65 & 1.86 & 1.89 & 2.45 \\
\hline $\begin{array}{l}\text { Saturated permeability } \\
K /(\mathrm{m} / \mathrm{d})\end{array}$ & 0.110 & 0.044 & 0.027 & - \\
\hline Initial moisture content $w_{0} /(\%)$ & 16.8 & 20.5 & 19.9 & - \\
\hline $\begin{array}{l}\text { Initial volumetric moisture } \\
\text { content } \theta_{0} /(\%)\end{array}$ & 24.0 & 31.6 & 31.4 & - \\
\hline $\begin{array}{l}\text { Initial matric suction } \\
\left(u_{a}-u_{w} \backslash_{0} /(\mathrm{kPa})\right.\end{array}$ & 18.3 & 9.2 & 25.1 & - \\
\hline
\end{tabular}

stability has no significant change. In the $9^{\text {th }}$ year, the groundwater rises up to submerge the lower portion of the sliding surface and the slope stability starts to decrease. During the drop break, the groundwater continues flowing from the inner to the slope toe. As a result the groundwater level beneath the slope toe continues rising. So in all the yearly periods, the slope stability becomes worse even after the water stops infiltrating.

Figure 18 shows the evolution of the factor of safety during water infiltration. During the first eight years, the factor of safety has no prominent decreasing and begins to lower in the $9^{\text {th }}-10^{\text {th }}$ years. The time coincides with the period that the groundwater level begins to touch the potential sliding surface and rises continuously. In addition, the moisture content of the slope above the groundwater level also increases which reduces the strength of the loess. All of these factors lead to the slope failure.

\section{Conclusions}

Loess is a typical unsaturated soil which is sensitive to moisture. In this paper, investigation demonstrates that

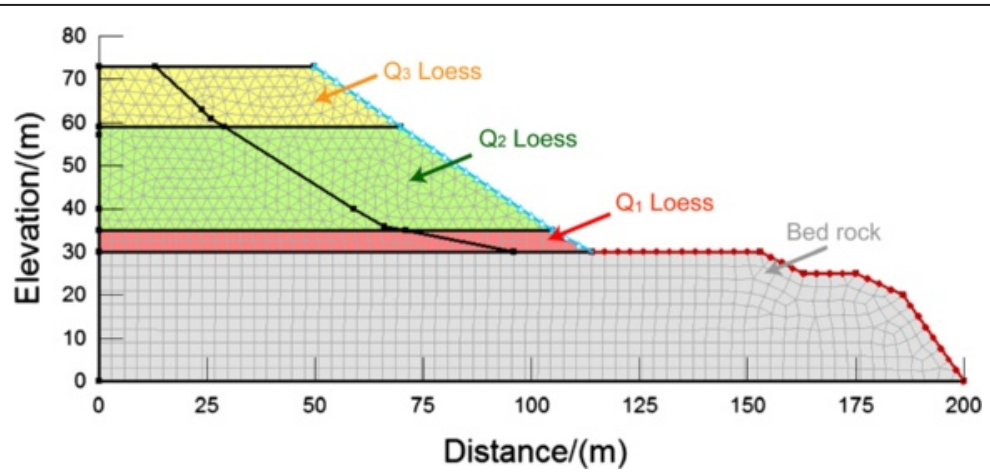

Fig. 16 FEM meshes of the slope model before failure $(F s=1.44)$ 

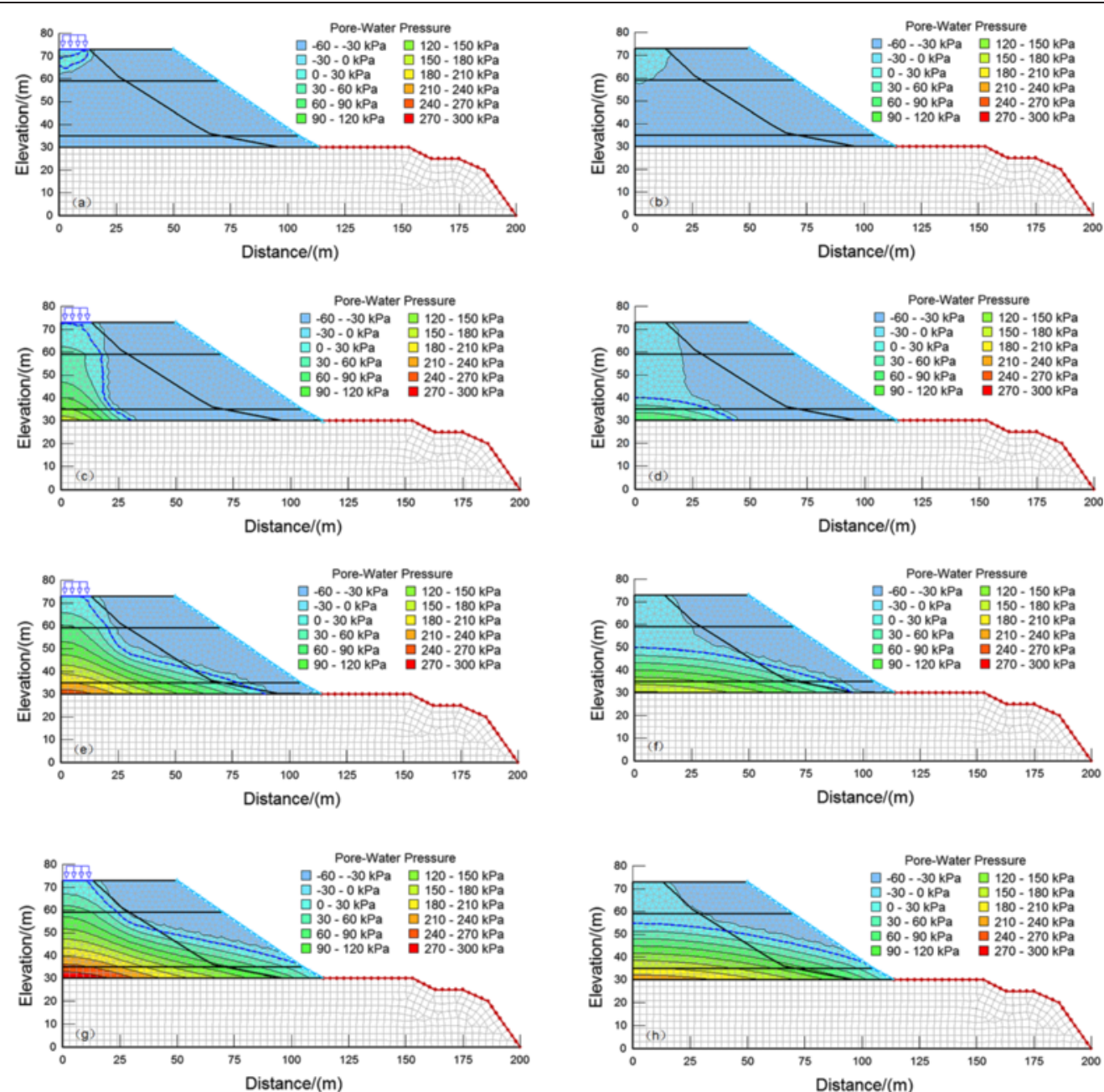

Fig. 17 The simulated results of the pore water pressure in the slope at different times (a) At the end of 100 days, Fs $=1.43$; (b) At the end of the first year, $F_{S}=1.43 ;$ (c) At the end of the $4^{\text {th }}$ year and 100 days, $F_{S}=1.44 ;$ (d) At the end of the $5^{\text {th }}$ year, $F_{S}=1.43 ;$ (e) At the end of the $9^{\text {th }}$ year and 100 days, $F_{S}=1.36 ;$ (f) At the end of the $9^{\text {th }}$ year, $F_{S}=1.29 ;(\mathbf{g})$ At the end of the $14^{\text {th }}$ year and 100 days, $F_{S}=1.03 ;(\mathbf{h})$ At the end of the $14^{\text {th }}$ year, $F_{S}=1.01$

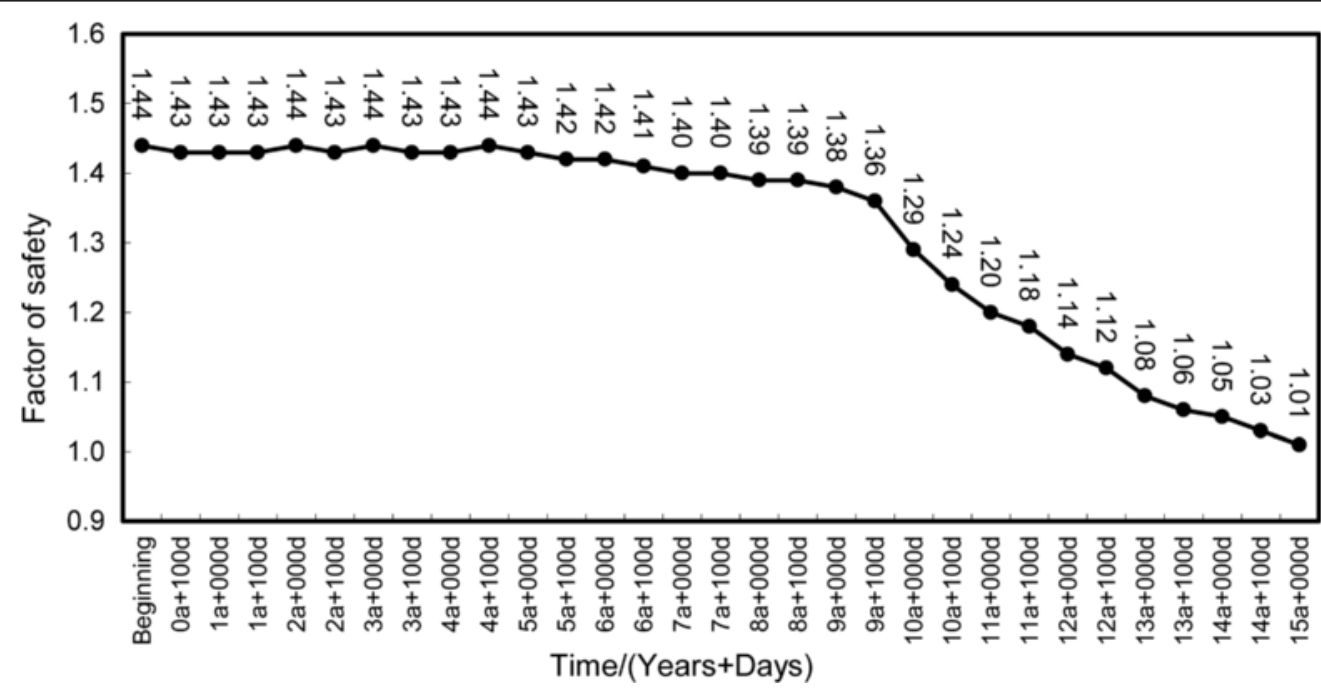

Fig. 18 The factor of safety varied with time 
long term condensed water vapor released from the pressure adjusters on the heating pipes which are used to keep the oil in the transfer pipes from frozen in winter is the triggering factor of the Yanlian landslide. Laboratory tests including conventional triaxial tests, consolidation quick shear tests and SWCC measurement are performed to estimate the unsaturated strength parameters and water conductivity.

The safety of factor can be figured out based on the moisture field and the stress field simulated by the FEM model with the parameters. The result shows that a little water infiltration has minor effects on slope stability for some time. As a result it is easy to be ignored. However, when the period of water infiltration is long enough to raise the groundwater level, it will have detrimental influence on the stability and the slope will fail at last. The analysis above illustrates that any minor water produced by engineering or other activities may have harmful effect on slope stability for a long period of action. Therefore it is essential to take account of this kind of water and adopt measures to curb the surface water infiltration and to drain the groundwater.

\section{Competing interests}

The authors declare that they have no competing interests.

\section{Authors' contributions}

All authors participated the field investigations. HS \& XZ conducted sampling and all the laboratory tests. XZ conducted graphing and analysis for the test results. HS conducted the numerical simulations. PL drafted the manuscript. All authors read and approved the final manuscript.

\section{Acknowledgements}

This research was funded by one of National Basic Research Program of China (2014CB744701) and National Natural Science Foundation of China (Program no. 41372329). The authors wish to acknowledge Dr. Austin ChukwuelokaOkeke, Department of Geoscience, Shimane University, for reading the manuscript and revising the English language. Our thanks also give to Dr. Xianli Xing, Department of Geological Engineering, Chang'an University, for her valuable guidance of the laboratory tests.

Received: 7 October 2014 Accepted: 27 April 2015

Published online: 17 September 2015

\section{References}

Bai MZ, Du YQ, Kuang X (2012) Warning Method and System in Risk Management for Loess Engineering Slopes. J Perform Constr Facil 26(2):190-196

Chillds EC, Collis-Geoge GN (1950) The permeability of porous materials. Proc R Soc London, Ser A 201:392-405

Dai FC, Lee CF (2001) Frequency-volume relation and prediction of rainfallinduced landslides. Eng Geol 59(3/4):253-266

Fredlund DG, Morgenstern NR, Widger RA (1978) The shear strength of unsaturated soils. Can Geotech J 15:313-321

Fredlund DG, Xing A (1994) Equations for the soil-water characteristic curve. Can Geotech J 31(3):521-532

Kunze RJ, Uehara G, Graham K (1968) Factors important in the calculation of hydraulic conductivity. Soil Sci Soc Am Proc 32:760-765

Lei XY (1994) The hazards of loess landslides in the southern tableland of Jingyang County, Shaanxi and their relationship with the channel water into fields (In Chinese). J Eng Geol 3(1):56-64

Li P, Zhang B, Li TL (2012) Study on Regionalization for Characteristic and Destruction Rule of Slope in Loess Plateau (In Chinese). J Earth Sci Environ 34(3):89-98
Li TL, Wang P, Xi Y (2013). Mechanisms for initiation and motion of Chinese loess landslides, Ed. by FawuWang, Masakatsu Miyajima, Tonglu Li,Wei Shan, Teuku Faisal Fathani, Progress of Geo-Disaster Mitigation Technology in Asia, Springer, Verlag Berlin Heidelberg:105-122.

Liao HJ, Su L, Li ZD, Pan YB, Fukuoka H (2008) Testing study on the strength and deformation characteristics of soil in loess landslides. Ed. by Chen Zuyu, Zhang Jianmin, Li Zhongkui, Wu Faquan, Ho Ken, Landslides and Engineered Slopes (from the Past to the Future), CRC Press, Leiden, The Netherlands, Vol 1:443-447.

Marshall TJ (1958) A relation between permeability and size distribution of pores. J Soil Sci 9:1-8

Tu XB, Kwong AKL, Dai FC, Tham LG, Min H (2009) Field monitoring of rainfall infiltration in a loess slope and analysis of failure mechanism of rainfall-induced landslides. J Eng Geol 105(1):134-150

Zhang JQ, Peng JB (2014) A coupled slope cutting - a prolonged rainfall-induced loess landslide: a 17 October 2011 case study. Bull Eng Geol Environ 73(4):997-1011

\section{Submit your manuscript to a SpringerOpen ${ }^{\circ}$ journal and benefit from:}

- Convenient online submission

- Rigorous peer review

- Immediate publication on acceptance

- Open access: articles freely available online

- High visibility within the field

- Retaining the copyright to your article

Submit your next manuscript at $\gg$ springeropen.com 